\title{
Cultural Based Ecolexical Erosion (Preliminary Study of Ecolexicon Shift in Lio Language, Flores)
}

\author{
Aron Meko Mbete ${ }^{1}$ \\ Program Pascasarjana Universitas Warmadewa ${ }^{1}$ \\ $\left\{\right.$ aronmbete@yahoo.com $\left.{ }^{1}\right\}$
}

\begin{abstract}
This paper describes the shift in the ecolexicons of the Lio, Flores language, which is shown through the phenomena of change and shifting of linguistic (and cultural) elements which are very clearly visible at the level of the lexicons, especially external referential conceptual lexicons. The unstable condition of bilingualism greatly affects the life of the Lio language in the future. Development without control and without paying attention to the cultural approach has an impact on symptoms of deprivation of the millennial generation from local cultural roots. The original staple food pattern which in practice for the older generation is always preceded by consuming seasonal and non-seasonal tubers, as well as seeds with various varieties of beans and maize before being "topped up" by the staple food of rice in the traditional Lio-Ende society, nowadays is increasingly fading and threatened with extinction, especially among the millennial generation. Various knowledge and experiences of speech community are interrelated and interact with diversity in their environment, recorded in language. Language changes reflect changes in the environment from time to time, which are reflected in the dynamics of the wealth of linguistic knowledge, especially lexicons owned by the community. One example of the lingual data markers of lexical erosion is Pare 'rice' (a type of Oryza) and kepare-an 'world of rice'. The original varieties of pare 'rice' with original names in Lio language began to erode (erosion). The following rice varieties no longer appear in the fields, among others: pare maru, pare sera ndori, pare ndale, pare sera, pare ndota, and pare leta robo. The presence of lexical erosion found in Lio language can have a cultural impact in the lexical erosion link, such as the shrinking of the rice fields which are full of ritual meaning in the mythological and cultural schemata of Ine Pare 'Dewi Padi', the change in the face of the land is replaced by a variety of trade crops which are very fast, have resulted in a culture and money economy (such as candlenut, cloves and cocoa), become the most dominant factor in displacing native plants which are very valuable in terms of food security. As indicated by the displacement of a set of lexicons, so did the dysfunction of texts on customary rituals, procedural texts of original pottery processing, and procedural texts of processing corn in particular, all of which had implications for changes in the mindset and work patterns of the people. To prevent ecolexical erosion that has an impact on culture, it can be done by reinforcement of traditional institutions with traditional leadership structures centered on The Sa'oria Tenda Bewa 'Lembaga Rumah Adat', as a government
\end{abstract}


partner in caring for and preserving local culture in the packaging of the local language Lio-Ende in particular, is a solution.

Keywords: ecolexicon; erosion; Lio Language

\section{Introduction}

Language has a very important role in human life. Humans and language are two things that are reciprocal, namely that they cannot be separated. Humans exist because language is a means of self-identification, as well as language exists because as users in the communication process in their lives. In this connection, Mbete (2009) states that language is not limited to being a communication tool. Language contains a cultural vision: recording, maintaining, and passing on collective concepts, historical, philosophical, socio-cultural and ecological values of a society. Language is a symbol and cultural element inherent in human life. In socioculturally, language is a cultural component that exists in a real way and can directly differentiate between one ethnic community and another. As a social reality, language is a phenomenon that is used by its speech community to communicate and interact in the context of situations and cultural contexts in an environment. In an ecolinguistic perspective, language and the speech community are seen as organisms that live systemically in an environment, along with other organisms. Thus, a language can develop according to the development of human culture and can easily change, shifting endlessly from time to time.

The phenomenon of change and shift in linguistic (and cultural) elements is clearly visible at the lexicon level, especially external referential conceptual lexicons. The lexicon is sensitive to change. In an ecolinguistic perspective, many lexicons, including terms, store ideology (Bundasgaard \& Steffenson in Lindo \& Bundasgaard, eds. 2000: 19). Likewise, in a dialectical ecolinguistic perspective, language which is understood as social practice has three dimensions: ideological, sociological, and biological. In the discussion of the Lio language, Flores, Lio is one of the local languages that is still alive. In Flores alone, there are seven local languages, namely: Manggarai, Komodo, Ngadha, Nage, Lio, Sikka, Lamaholot, and Larantuka Malay dialect. The Lio language still functions, among other things, to store local knowledge and accommodate community activities and local culture. In addition, this language also marks the social practice of the Lio ethnic community in maintaining a spiritually-transcendental harmonious relationship with their ancestors.

The unstable condition of bilingualism greatly affects the life of the Lio language in the future. As is the case in many regions of Indonesia, it is inevitable that the development of the Indonesian language as the national language, official language, and state language, the phenomenon of shrinking the socio-cultural functions of the local language has occurred massively. Such conditions should not displace the life of local languages or regional languages as long as the behavior of "sharing functions and domains" between Indonesian and regional languages can be structured in a more conceptual manner.

Words, including lexicons and terms, are "new home" universal meaning (Taylor, in Gibbons, 2004). In connection with this conceptual framework, the external referential function of the word becomes a very important "bridge" link between linguistic signs and the reality of environmental entities. The word, thus, can be used as a means of tracking the existence of various real entities referred to by words in the language and cultural environment 
in which the language lives. Likewise, a set of lexicons in the language, culture and environment of the Lio, Flores language assists in this tracing. Through observation, thematic interviews, and focused discussions with a number of older and young speakers, especially by exploring personal experiences, data and facts about ecolexical gaps and their cultural impacts can be uncovered.

In particular, this study utilizes the environment of two villages, namely Wolosoko and Wolotolo Village, Ende Regency, Flores, East Nusa Tenggara as research locations. The choice of the two locations was based on the fact that apart from farming with original field rice as the superior among the various horticultural crops, specifically the economic life of a number of its residents has been supported for a long time by crafting pottery which in the local language is known as ju podo $k(h) a w a$ 'ceramic craftsman'.

Although there are differences in views, language is essentially (also) a nomenclature (Saussure, 1973; 1988; Culler, 1996). Various knowledge and experiences of speech community are interrelated and interact with diversity in their environment, recorded in language. This knowledge and experience includes both animate (biotic) and inanimate (abiotic) entities that are lingually coded, spoken of, and passed on from generation to generation. In linguistically-culturally, the names of flora and fauna, utilization of land, stone and water resources with traditional technology are full of meaning and rich in value for people, in the context of this paper, the speech community of Lio language, Flores.

Time is passing by. Traditional societies, cultures, civilizations and technologies change. Development in all areas of life has accelerated the rate of change and changed the social, cultural, economic and environmental orders. The traditional pattern of intercropping-based farming has also changed. The original fields with an intercropping pattern with local rice as the superior, "center" and full of rituals in the Lio ethnic community, Flores, are increasingly eroded and changing shape. Local native-land rice with its various varieties, including sorghum and various native plants as food sources, is starting to disappear. Lexical erosion (see Pandey, in Lindo and Bundasgaard, 2000), which also marks genetic erosion (Setiadi, tt), is a direct result of development. Development without control and without paying attention to the cultural approach has an impact on symptoms of deprivation of the millennial generation from local cultural roots.

The original staple food pattern which in practice for the older generation is always preceded by consuming seasonal and non-seasonal tubers, as well as seeds with various varieties of beans and maize before being "topped up" by the staple food of rice in the traditional Lio-Ende society, nowadays is increasingly fading and threatened with extinction, especially among the millennial generation.

\section{Method}

This research is a field research conducted in Flores, East Nusa Tenggara, namely in Ende District, Wolosoko and Wolotolo Village. The method used is a qualitative approach by tracking a set of lexicons in the language, culture and environment of the Lio, Flores language through observations, thematic interviews, and focused discussions with a number of older and young speakers, in particular by exploring personal experiences, data and gaps facts of ecolexical, and its cultural implications can be uncovered. 


\section{Discussions}

\subsection{Lingual Data Snippet for Lexical Erosion Markers}

Language changes reflect changes in the environment from time to time, which are reflected in the dynamics of the wealth of linguistic knowledge, especially lexicons owned by the community. The following is an excerpt of the lingual data of the Lio language as a marker of lexical erosion.

\subsubsection{Lexicon set is categorized as biotic}

1) The name of plants (as cultural flora) which are the staple food sources.

a) Pare 'rice' (a type of Oryza) and ke-pare-an 'world of rice'. The original varieties of pare 'rice' with original names in tLio language began to erode (erosion). The following rice varieties no longer appear in the fields, among others: pare maru, pare sera ndori, pare ndale, pare sera, pare ndota, and pare leta robo.

b) Lolo 'sorghum' has varieties such as: lolo telo leko, lolo teke toros have no longer appeared in the Lio field. Even the lolo 'sorghum' crop has almost disappeared from the fields and is getting away from the staple food line. In fact, the intercropping system with pare "rice" as the main crop and lolo 'sorghum' which functions as a protector of pare "rice" from poultry pests, are very important to be present in the plant treasures, original food treasures and local lexicons of Lio language.

c) Jawa 'corn' is still quite strong to be maintained in the people's fields. However, the original manually processed types of food made from the jawa 'corn' with the name khashu'u, also in some versions, have started to fade. In fact, the food has a long enough shelf life for several months and even years if stored in a dry place, usually on top of the shelf. Likewise, verb of pena jawa to process corn into ready-to-cook small grains' has been replaced by the absorption verb from Indonesian gili 'to grind'. A shift also occurs in the verb to jawa "to make corn chips" (titi corn), seo jawa 'to fry corn without oil' which has also been lost from the practice of social speech community in Lio language.

d) Wete 'jewawut' is a nutritious refined grain plant. This plant is usually planted on the edge of the field while at the same time controlling poultry pests, especially rice-eating sparrows. Apart from being a staple food, these plants are also used as ritual ingredients.

e) Nggoli and pega, two types of local food-producing grains that were once planted on the edge of the fields, are now disappearing.

f) Uwi 'tubers' and uwi kaju 'cassava' in particular also have their own position in the food culture of the local community. The legacy of the staple food comes from quite a lot of tubers, although some of the varieties now have names and memories. Uwi varieties such as: uwi nio, uwi lea, uwi leke, uwi manu, are extinct. Likewise, ndelo and suja. Cassava varieties have also shrunk.

2) Wild animals in the form of kamba 'buffalo' and wawi ndua 'wild boar' which inhabit forests, grasslands and bushes, also only leave memories. Illegal hunting is the dominant factor apart from changes in land and forest functions. Several names such as: hutu 'hedgehog', beku "civet", dheke 'mongoose' have also disappeared. The spread of commercial crops such as cloves, candlenut, cacao, has also destroyed original crops and diminished the natural habitat of these wild animals. 


\subsection{Lexicon set is categorized as a-biotic}

\subsubsection{Ceramic Crafts and Lontar-Pandan Leaves Lexicon Set}

1) Lexicon set of earth-based kitchen and ritual equipment

a) Lexicons: podo 'pan', hawa 'pan', pane 'earth dish', pane gamo or paso 'water basin', pane ae 'place to drink' are rare. The original furniture has been displaced by new furniture made from glass, not soil anymore, as well as the Indonesian name (plate, glass, pan, although in traditional rituals such as mbama ritual 'thanksgiving', pesa uta dowe 'the first corn harvest ritual', the original furniture from the land is still used, along with woven furniture made of palm and pandan leaves. The lexicon ae gomo 'water well', ae labo 'water installation from bamboo or betung' replaced by iron pipe, $p o^{\prime} o$ displaced the words ember and jerry cans'.

2) Original food preservative and storage equipment

a) Sobe 'a kind of meat preservative' shifted by the refrigerator.

b) Wati, wati jando, two containers of rice and or rice have now disappeared, replaced by imported goods such as zinc plates. Benga and bote, which contain after-harvest field rice, have also become extinct.

c) The 'original rice barn' kebo has also disappeared. In fact, the original rice culture in Lio language congregation is classified as ancient or original Austronesian culture. The evidence for the lexicon kebo comes from the ancient Austronesian language * kebaw.

\subsection{Cultural Impact in Lexical Erosion Relationships}

a) Depreciation of the number of original words as a wealth of Lio's language and culture is the impact. Vocabulary such as the lexical data found above is no longer familiar among Lio's younger generation, even among the elderly.

b) The shift in the cultural pattern from the arrangement (traditional menu composition) of original staple foods which is actually more varied to be very 'monoculture'. Clearly, the staple food composition of the original food diversity pattern which is directly related to the availability of various seed and tuberous plants as gifts of nature has changed drastically. The habits of the older generation in general, which eat tubers first, especially cassava before enjoying rice, have faded among the millennial generation. Cassava or cassava with a variety of processed shapes and textures is equally delicious (for example, kaju lamu, kaju dhe, or also typical processed packaging such as: kaju kedho, kaju dhara which has been fermented beforehand), are no longer populist and are no longer popular with the millennial generation.

c) From a cultural perspective, the agility and the image of the taste of the tongue, which was originally familiar with local culinary mixtures, especially the molars of the older generation have faded among the young. Now the millennial generations has shifted or have abandoned old eating habits or patterns. This shift has an impact on the rarity of the millennial generation to enjoy staple foods with the old order, namely enjoying tubers including corn and sorghum. The thickness of culture, in the sense that it only prefers rice (rice oriented), on the instant noodles side and the like is a fact of change that has a cultural impact. Since the New Order government program in the 1970s, which was also, accelerated and be classified by the 'rice for the poor' program, Raskin over the 
last decade, the old diet has completely replaced rice for most of the millennial generation.

d) The shrinking of the rice fields which are full of ritual meaning in the mythological and cultural schemata of Ine Pare 'Dewi Padi', the change in the face of the land is replaced by a variety of trade crops which are very fast, have resulted in a culture and money economy (such as candlenut, cloves and cocoa), become the most dominant factor in displacing native plants which are very valuable in terms of food security. As indicated by the displacement of a set of lexicons, so did the dysfunction of texts on customary rituals, procedural texts of original pottery processing, and procedural texts of processing corn in particular, all of which had implications for changes in the mindset and work patterns of the people.

e) The fading of original tubers and seeds is also an effect. The disappearance of the staple food plants has a very big effect on the culture of the tongue, from the old habit of chewing corn which is useful for strengthening molar teeth, now the millennial generation is more spoiled by the sheer tenderness of rice and super pleasures. In fact, local food security is based on the availability of tubers and seeds from intercropping cultivation patterns. Cassava which is known as the granary (in) the soil, as well as a number of other tubers, many of which have become extinct. Only in a number of villages in the interior of Lio Ende do the buildings of kebo 'barn' remain as original buildings in the context of rice culture.

f) The original farming culture with a number of palawija plants with original local rice has also changed. Working on the farm in the fields, known in the Lio language as gaga bene 'managing the fields', has replaced the economy with ojeg transportation services. The presence of ojek also diminishes and even fades the habit of walking, an original sport that is easy, cheap and natural.

g) The impact of symbolic meaning in other lingual-cultural expressions in social life is also interesting to note. Greetings with the nuanced litotes before meals and inviting or inviting guests: 'Maisai ... we know ka uwi kaju salo'o' which literally means: 'Let's eat cassava in moderation', began to fade as well. In fact, the attitude of respect and humiliation as the host of guests, as seen in the verbal expression, is one of the important characters of the Lio people in maintaining harmonious relationships with each other, especially with groups that are respected.

h) The inadequacy of serving the main food elements in the ancestral Pati Ka ritual also began to be felt and realized by the older generation of Lio. The Lio people, like the Flores people, generally have a special relationship and respect for their ancestors (see Koentjaraningrat, 1990). The mera area of 'red rice' from the original rice suppliers of red rice originating from their land or heritage land and their ancestral heritage is the absolute and most appropriate requirement when the family holds the pati ka ritual 'food offering', either from time to time or during the mbama ritual joka ju, and so on. In other words, it is not rice that is bought in the shop that is offered but rice from native rice which is considered worthy and worthy of acceptance by the ancestors.

i) Land resources that support the economic business of the dry season after the rice field harvest, which is also one of the choices for vocational skills for professional preparation, are affected by new technology. The loss of the ju tana 
"ceramic craftsman" profession as well as the 'palm sugar craftsman' kewi moke because the palm land which is seized by commercial plants has resulted in changes in behavior and professions. Even though the availability of types of clay for ceramics is still quite available, as is the population of palm which is still quite promising.

\section{Conclusions}

Based on the explanations that have been discussed in the discussion, the writer can draw several conclusions.

a) Re-awareness through critical and constructive eco-literacy education needs to be carried out systematically and continuously for young speakers, adolescents, and children.

b) Local government regulations and role models from the top, especially the local government in using native products and native plants are expected. Regulation in the sense of developing a creative economy based on local cultural resources, cultural plants and animals, as well as land resources for the development of creations and innovation in ceramic crafts and skills, is very important in the midst of the COVID19 pandemic.

c) Reinforcement of traditional institutions with traditional leadership structures centered on The Sa'oria Tenda Bewa 'Lembaga Rumah Adat', as a government partner in caring for and preserving local culture in the packaging of the local language Lio-Ende in particular, is a solution. Likewise, the re-functioning of customary institutions because it is related to the inheritance and integrity of farming rituals centered on traditional houses is a very important solution option.

d) The cultivation of traditional local values that have the potential to strengthen the roots of life amid conditions of dislocation and orientation through formal educational institutions is very important and strategic. Language learning (Indonesian, regional, and foreign) with local content proportionally, is highly desirable.

e) Change is indeed a historical necessity. However, development and modernization, or the globalization of culture and language facilitated by advances in digital technology, nevertheless has local and national roots. Indonesian identity is also characterized by the national language of Indonesia, and Indonesian identity as a nation state is still supported by local pillars based on ethnic communities, and of course ethnic languages as the wealth of Indonesians.

\section{References}

[1] Bundasgaar, Jeppe \& Sune Steffenson, 2000 'The Dialectics of Ecological Morphology-or the Morphology of Dialectics' dalam Anna Vibeke Lindo \& Jeppe Bundasgaard (eds.) 2000. Dialectical Ecolinguistics. Odense: University of Odense.

[2] Culler, Jonathan, 1990. Saussure. Terjemahan Rochayah dan Siti Suhayati. Jakarta: Pusat Pembinaan dan Pengembangan Bahasa. 
[3] De Saussure, Ferdinand 1988. Pengantar Linguistik Umum. Terjemahan Rahayu S. Hidayat. Yogyakarta: Gadjah Mada University Press.

[4] Gibbons, Michael T. 2002. Tafsur Politik. Telaah Wacana Sosial-Politik Kontemporer. Yogyakarta: Qalam.

[5] Lindo Vibeke \& Jeppe Bundsgaard (eds) 2000. Dialectical Ecolinguitics. Three Essays For The Symposium 30 Years of Language and Ecology in Graz December 2000. Udinese: University of Udinese.

[6] Mbete, Aron Meko dkk. 2008. Nggua Bapu. Ritual Perladangan Etnik Lio-Ende. Yogyakarta: Pustaka Larasan.

[7] Orienbao, P Sareng 1989. Tata Berladang Tradisional dan Pertanian Rasional SukuBangsa Lio. Ledalero, Nita, Flores: Seminari Tinggi St. Pailus.

[8] Pandey, Anjali, 2000 'Linguitics Erosion on the Chesapeake: Intergenerational Diacronic Shitf in Lexicalizations of The Bay" dalam Anna Vibeke Lindo \& Jeppe Bundasgaard (eds.) 2000. Dialectical Ecolinguistics: Three Essays For The Symposium 30 Years of Manguage and Ecology in Graz December 200. Language and Ecology Vol 2 N0 3. www.ecoling.net/journal.html.

[9] Setiadi, Sukiswo, tt. "Dampak Pembangunan pada Komponen Hayati". Kumpulan Makalah: (I) Kursus Dasar-dasar Analisis Mengenai Dampak Lingkungan. Jakarta: Pusat Penelitian Sumberdaya Manusia dan Lingkungan Universitas Indonesia.

[10] Taylor, Charles 2002 "Bahasa dan Hakikat Manusia' dalam Michael T. Gibbons (Ed), Tafsir Politik: Telaah Hermeneutis Wacana Sosial Kontemporer. Yogyakarta: Qalam 